\title{
EVALUATION OF MAXILLOFACIAL INJURIES AND ITS MANAGEMENT
}

\author{
Vijay Krishan Agarwal', Sandeep Kansal2, Dhanesh³, Shitij Arora ${ }^{4}$, Ankit Garg ${ }^{5}$
}

1 Professor, Department of General Surgery, Chhatrapati Shivaji Subharti Medical College, Meerut, Uttar Pradesh, India. ${ }^{2}$ Associate Professor, Department of General Surgery, Chhatrapati Shivaji Subharti Medical College, Meerut, Uttar Pradesh, India. ${ }^{3}$ Associate Professor, Department of General Surgery, Chhatrapati Shivaji Subharti Medical College, Meerut, Uttar Pradesh, India. ${ }_{4}^{4}$ nd Year Junior Resident, Department of General Surgery, Chhatrapati Shivaji Subharti Medical College, Meerut, Uttar Pradesh, India.

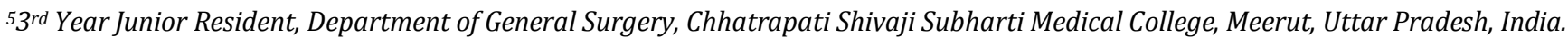

\section{ABSTRACT}

\section{BACKGROUND}

The face is one of the most significant parts of the body. It is involved in many of our senses- sight, smell, taste and hearing. Traumatic injury contributes to the global health burden. Oral and Maxillofacial Injuries (OMFIs) are commonly associated with general body injuries.

The aim of this study is to identify the presentation of maxillofacial injuries and its management in western Uttar Pradesh, India.

\section{MATERIALS AND METHODS}

In Emergency Department of Chhatrapati Shivaji Subharti Hospital, Meerut, 116 patients who came with complaints of road traffic accident, interpersonal injuries, sports related injuries, fall from height, blast injuries, penetrating injuries, firearm injuries, animal bite, human bite, resulting in head injuries, facial trauma, cervical injuries and neck injuries, crushed injuries from $1^{\text {st }}$ June 2017 till $20^{\text {th }}$ August 2018 were taken into consideration.

Most of the patients admitted here were referral cases from nearby territories and nursing homes. We collected data from the hospital records regarding name, age, sex and place from where they were brought. Radiographs of patients who were referred and hospitalised for treatment were reviewed.

\section{RESULTS}

Maximum number of patients belong to 21 years - 40 years of age with male predominance. Road side accident came out to be major cause of facial injury. Mandible fracture involving parasymphysis is the most common fracture noted. Most of the fractures are treated by open reduction and internal fixation.

\section{CONCLUSION}

Maxillofacial injuries are mostly due to high velocity traffic. Management of these injuries have become easier with availability of mini plates and screws, because of which there is decrease in morbidity as little or no intermaxillary fixation required. Therefore, we prefer to treat maxillofacial injuries with open reduction and internal fixation with mini plates and screws.

\section{KEY WORDS}

ORIF (Open Reduction and Internal Fixation); Maxillofacial Injuries; RTA; IMF.

HOW TO CITE THIS ARTICLE: Agarwal VK, Kansal S, Dhanesh, et al. Evaluation of maxillofacial injuries and its management. J. Evolution Med. Dent. Sci. 2018;7(42):4566-4570, DOI: 10.14260/jemds/2018/1018

\section{BACKGROUND}

The face is one of the most significant parts of the body. It is involved in many of our senses- sight, smell, taste and hearing. It is how we eat and breathe. It is involved with communication, either verbally or more importantly nonverbally. We use it to smile, to frown and to cry. It is how we project to others so many of our thoughts and feelings. For these reasons, facial injuries or disfigurement that tend to take on more significance, at least psychologically than injuries to other anatomical regions. Phipps and Shelton ${ }^{[1]}$ presented a case where medical treatment was forgone on the basis that the patient although having survivable injuries

'Financial or Other Competing Interest': None.

Submission 30-08-2018, Peer Review 28-09-2018,

Acceptance 03-10-2018, Published 15-10-2018.

Corresponding Author:

Dr. Sandeep Kansal,

Department of General Surgery,

Chhatrapati Shivaji Subharti Medical College,

Meerut, Uttar Pradesh, India.

E-mail: drsandeepkansal@gmail.com

DOI: $10.14260 /$ jemds $/ 2018 / 1018$ would be left without a face. It is important for the medical staff, especially in the acute phase that they do not allow issues to affect their clinical judgement and management of these patients.

Traumatic injury contributes to the global health burden.[2,3] Oral and Maxillofacial Injuries (OMFIs) are commonly associated with general body injuries. Traumatic injuries to the head are of particular concern, due to the risk of intracranial injury. These types of injuries can be present with facial bone fractures, which may initially go unnoticed if a patient has multiple system traumas or other pressing medical concerns. ${ }^{[4]}$ The risk of missed diagnosis of fracture may also increase when trauma patients are admitted to hospitals with limited or no accompanying information about their injuries or do not have any visually apparent facial injuries. For example, patients can enter emergency departments intoxicated, sedated, intubated, with varying levels of consciousness or otherwise unable to clearly report injuries.

Facial bone fractures result from a transfer of energy to an area of a facial bone unable to sustain the force. Common causes of facial fractures include blunt trauma as seen in 
automobile accidents, assaults, falls and sports.[5,6] The bony prominences of the face serve as protective structures of the underlying skull and are at risk for fractures during any type of collision. Primary types of facial fractures seen in trauma patients include those of the nasal, mandible, maxillae and orbital bones,[7,8,5] which can be dependent on the source population. Fractures are classified as closed, open, displaced, non-displaced and by their anatomical location.

The degree of OMFIs largely depends on the aetiology and the activities the victim is involved in. The prognosis of the injured patient is dependent on both the initial emergency treatment and the eventual definitive treatment given to the victim. Both forms of treatment are dependent on availability of the necessary facilities and expertise in a given health facility that attends to the patient.

\section{MATERIALS AND METHODS}

In Emergency Department in Chhatrapati Shivaji Subharti Hospital, Meerut, there were a total of 116 patients who came with complaint of road traffic accident, interpersonal injuries, sport related injuries, fall from height, blast injuries, penetrating injuries, firearm injuries, animal bite, human bite, resulting in head injuries, facial trauma, cervical injuries and neck injuries, crushed injuries from $1^{\text {st }}$ June 2017 till 20 August 2018 were taken into consideration.

Most of the patients admitted here were referral cases from nearby territories and nursing homes. We collected data from the hospital records regarding name, age, sex and place from where they were brought. The radiographs of patients who were referred and hospitalised for treatment were reviewed.

\section{RESULTS}

Maximum number of patients belonged to 21 years - 40 years of age with male predominance. Roadside accidents are the major causes of facial injury. Mandible fracture involving parasymphysis is the most common fracture noted. Most of the fractures are treated by open reduction and internal fixation.

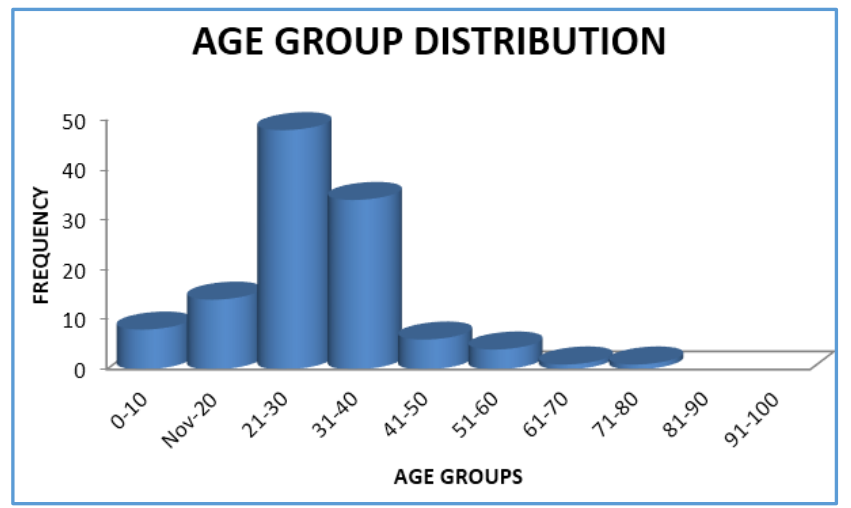

Figure 1

\section{SEX DISTRIBUTION}

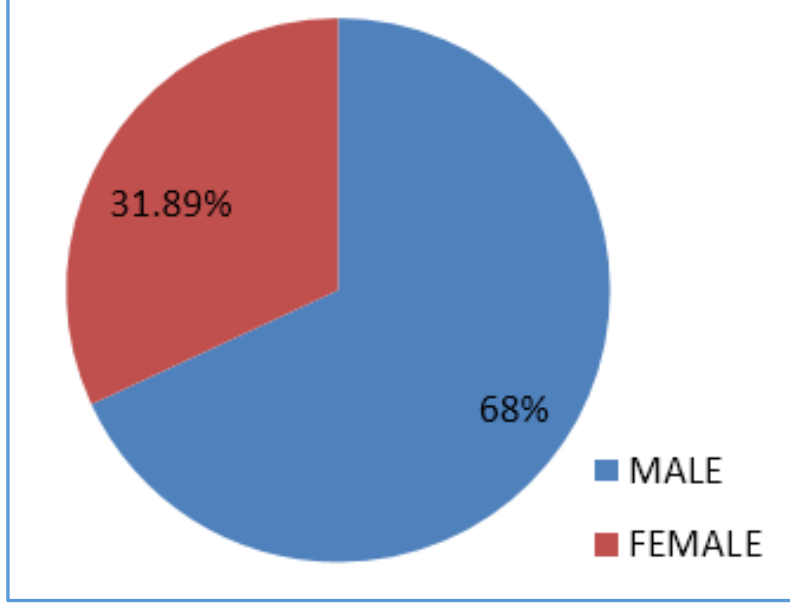

Figure 2

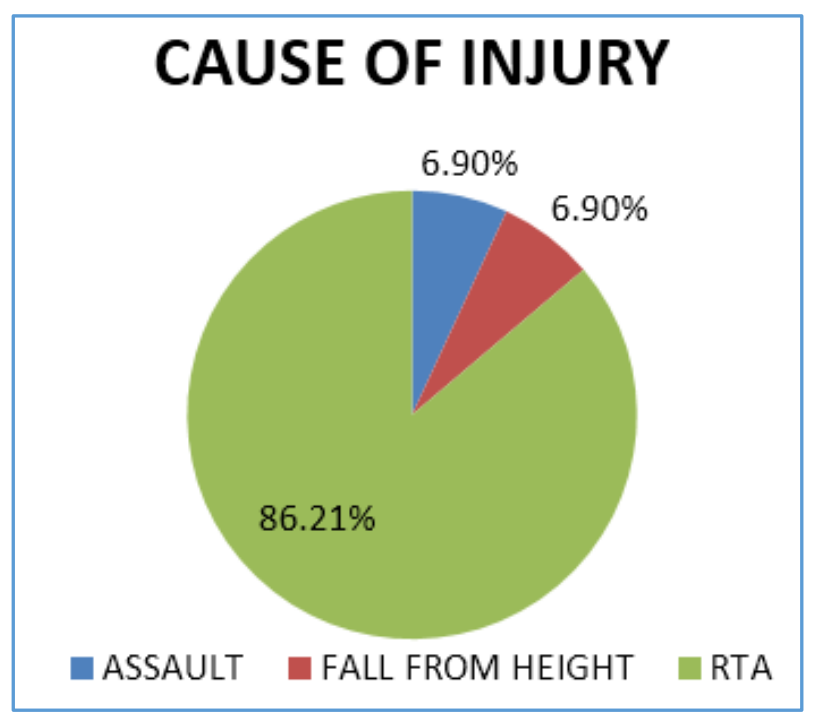

Figure 3

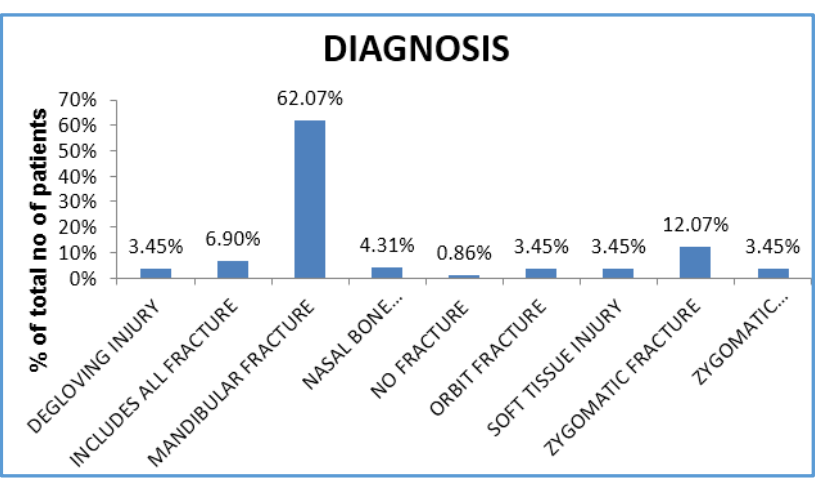

Figure 4 


\section{OPERATION DONE}

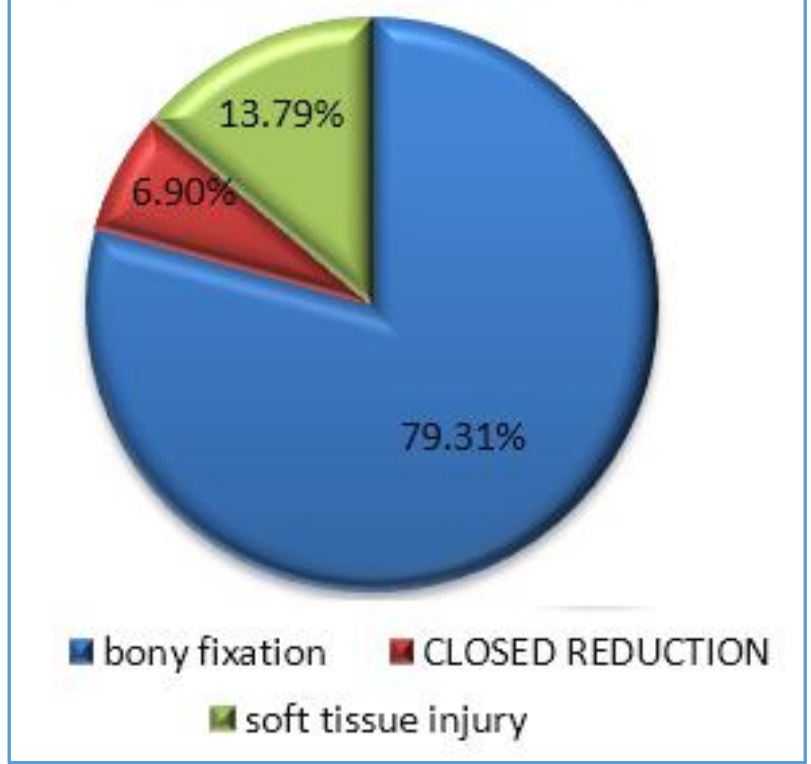

Figure 5

Diagnosis * Operation Done

\begin{tabular}{|c|c|c|c|c|c|}
\hline & \multicolumn{3}{|c|}{ Operation Done } & \multirow[b]{2}{*}{ 苟 } & \multirow[b]{2}{*}{$\begin{array}{l}0 \\
\frac{\pi}{2} \\
0 \\
0\end{array}$} \\
\hline & 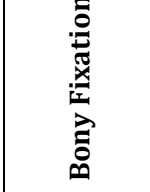 & 窇 & 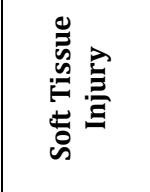 & & \\
\hline \begin{tabular}{|c} 
Degloving \\
injury
\end{tabular} & $\begin{array}{c}0 \\
(0.00 \%) \\
\end{array}$ & $0(0.00 \%)$ & $\begin{array}{c}4 \\
(100.00 \%) \\
\end{array}$ & $\begin{array}{c}4 \\
(100.00 \%) \\
\end{array}$ & \\
\hline \begin{tabular}{|c|c}
$\begin{array}{c}\text { Includes } \\
\text { all } \\
\text { fractures }\end{array}$ \\
\end{tabular} & $\begin{array}{c}8 \\
(100.00 \%)\end{array}$ & $0(0.00 \%)$ & $\begin{array}{c}0 \\
(0.00 \%)\end{array}$ & $\begin{array}{c}8 \\
(100.00 \%)\end{array}$ & \\
\hline $\begin{array}{c}\text { Mandibul } \\
\text { ar } \\
\text { fracture }\end{array}$ & $\begin{array}{c}64 \\
(88.89 \%)\end{array}$ & $\begin{array}{c}8 \\
(11.11 \%)\end{array}$ & $\begin{array}{c}0 \\
(0.00 \%)\end{array}$ & $72(100.00 \%)$ & \\
\hline 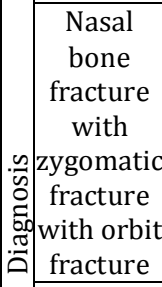 & $\begin{array}{c}5 \\
(100.00 \%) \\
\end{array}$ & $0(0.00 \%)$ & $0(0.00 \%)$ & $5(100.00 \%)$ & \\
\hline \begin{tabular}{|c|} 
No \\
fracture
\end{tabular} & $\begin{array}{c}1 \\
(100.00 \%)\end{array}$ & $0(0.00 \%)$ & $0(0.00 \%)$ & $1(100.00 \%)$ & \\
\hline $\begin{array}{c}\text { Orbit } \\
\text { fracture }\end{array}$ & $0(0.00 \%)$ & $0(0.00 \%)$ & $\begin{array}{c}4 \\
(100.00 \%)\end{array}$ & $4(100.00 \%)$ & \\
\hline $\begin{array}{c}\text { Soft tissue } \\
\text { injury }\end{array}$ & $0(0.00 \%)$ & $0(0.00 \%)$ & $\begin{array}{c}4 \\
(100.00 \%)\end{array}$ & $4(100.00 \%)$ & \\
\hline $\begin{array}{l}\text { Zygomatic } \\
\text { fracture }\end{array}$ & $\begin{array}{c}10 \\
(71.43 \%) \\
\end{array}$ & $0(0.00 \%)$ & $4(28.57 \%)$ & $14(100.00 \%)$ & \\
\hline $\begin{array}{l}\text { Zygomatic } \\
\text { fracture } \\
\text { with orbit } \\
\text { fracture }\end{array}$ & $\begin{array}{c}4 \\
(100.00 \%)\end{array}$ & $0(0.00 \%)$ & $0(0.00 \%)$ & $4(100.00 \%)$ & \\
\hline Total & $\begin{array}{c}92 \\
(79.31 \%)\end{array}$ & $\begin{array}{c}8 \\
(6.90 \%)\end{array}$ & $\begin{array}{c}16 \\
(13.79 \%)\end{array}$ & $\begin{array}{c}116 \\
(100.00 \%)\end{array}$ & \\
\hline
\end{tabular}

\section{Diagnosis * Operation Done}

\begin{tabular}{|c|c|c|c|c|c|}
\hline & \multicolumn{2}{|c|}{ Operation Done } & \multirow[b]{2}{*}{ Total } & \multirow{2}{*}{$\begin{array}{c}\text { P } \\
\text { value }\end{array}$} \\
\hline & & $\begin{array}{c}\text { Bony } \\
\text { Fixation }\end{array}$ & $\begin{array}{c}\text { Closed } \\
\text { Reduction }\end{array}$ & & \\
\hline \multirow{3}{*}{ 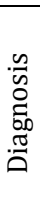 } & $\begin{array}{c}\text { Condyle } \\
\text { mandible }\end{array}$ & $\begin{array}{c}4 \\
(50.00 \%)\end{array}$ & $\begin{array}{c}4 \\
(50.00 \%)\end{array}$ & $\begin{array}{c}8 \\
(100.00 \%)\end{array}$ & \multirow{4}{*}{0.001} \\
\hline & Mandible body & $4(100.00 \%)$ & $\begin{array}{c}0 \\
(0.00 \%)\end{array}$ & $\begin{array}{c}4 \\
(100.00 \%)\end{array}$ & \\
\hline & $\begin{array}{c}\text { Parasymphysis } \\
\text { mandible }\end{array}$ & $56(93.33 \%)$ & $\begin{array}{c}4 \\
(6.67 \%)\end{array}$ & $\begin{array}{c}60 \\
(100.00 \%) \\
\end{array}$ & \\
\hline & Total & $\begin{array}{c}64 \\
(88.89 \%) \\
\end{array}$ & $\begin{array}{c}8 \\
(11.11 \%)\end{array}$ & $\begin{array}{c}72 \\
(100.00 \%) \\
\end{array}$ & \\
\hline \multicolumn{6}{|c|}{ Table 2} \\
\hline
\end{tabular}

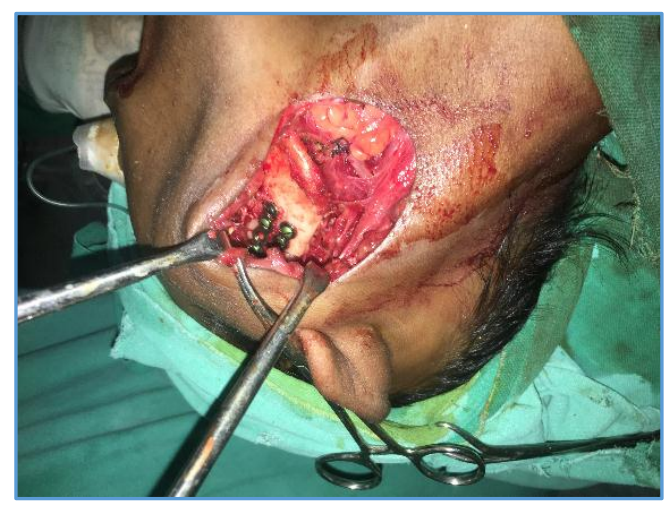

Intraop

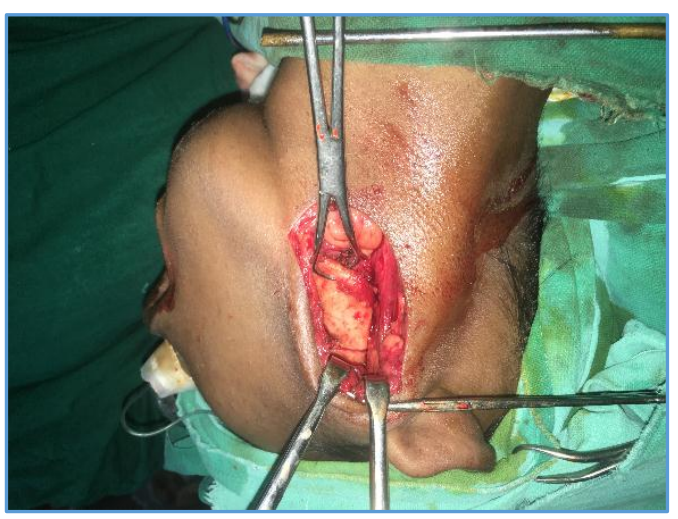

Intraop

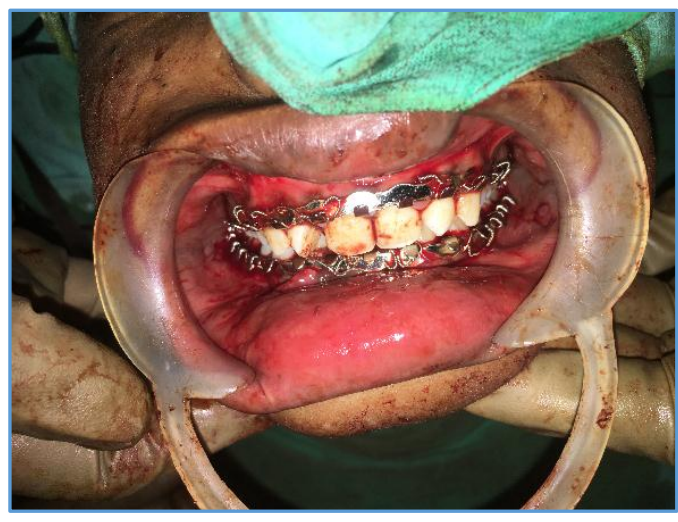

Postop

\section{DISCUSSION}

In developing countries like ours, traffic accidents remain the major cause of facial trauma.[9] A WHO statistics report indicated that each year one million people die and between 15 and 20 million are injured due to Road Traffic 
Accidents.[10] These include Motor Vehicle Accidents (MVAs), Motorcycle Accidents (MCAs) and bicycle accidents. This can be attributed to poor road infrastructure among other factors. Some of the vehicles are mechanically defective and are therefore more likely to get involved in road traffic crashes.

The motorcycle transport system has evolved as a means of circumventing traffic jams on major roads in western Uttar Pradesh and for its ability to pass through difficult terrain inaccessible to standard four-wheel vehicles. In addition to its versatility, the motorcycle is an Ellis, E $3^{\text {rd }}$, Moos KF and elAttar A. Ten years of mandibular fractures: An analysis of 2137 cases. Oral Surg. Oral Med. Oral Pathol 1985;59(2):1209 affordable alternative means of transport for many people. Furthermore, most of the riders are self-trained with hardly any knowledge of road traffic rules making a ride on a motorcycle highly prone to accidents.

In developing countries, traffic accidents remain the major cause of facial trauma. Literature reviewed shows that mandibular fractures are more common than mid-face fractures.[11-25]

Most facial bone fractures involve the mandible and this might be related to the direction and quantity of force that the mandible is exposed to. ${ }^{[18]}$ The mobility of the mandible and the fact that it has less bony support than the maxilla has also been implicated in its cause of Injury.[26] The body of the mandible was the most common mandibular fracture site.[16,23,24,27,28] Same pattern is seen in our study, $27 \%$. Patients with mandibular fractures caused by alleged assault had mandibular body fractures accounted for 33\% followed by the angle of the mandible 31\%.[29] In our study condylar fractures were $21 \%$, because it was not due to assault on the face but it was the result of RTA. Ramus, coronoid and dentoalveolar regions being the least common sites of mandibular fractures 10, 2 and $2 \%$ respectively. Fractures of the mid-face are rarer than lower jaw fractures. Mid-face fractures are often associated with fractures to the other parts of the central face. Maxilla acts as a central support bone in the face and impact to it can affect bone around the nose and the eye. The three ways in which fractures of maxilla occurs are Le Fort I fracture, which is a (horizontal crack across the maxilla, which separates off the maxilla and teeth from the bone above [Fig. 1 and 2]. Le Fort II fracture forms a line from the sides of the maxilla and over the nose [Fig. 3 and 4] and the Le Fort III fracture (Break in the eye socket and bridge of the nose [Fig. 5 and 6]. International studies from Jordan,[30] Singapore[31] and New Zealand[32] have reported RTAs as the most common cause of maxillofacial fractures, while in the USA, ${ }^{[33]}$ Sweden[34] and Finland[35] assault has been reported as the leading aetiological factor. Male-to-female ratio was found to be 3.5:1. This ratio is comparable with studies from England,[25] France, ${ }^{[36]}$ India[25] and Nigeria.[28] Most of the literature concludes with the fact that the incidence of road traffic accidents is comparatively more in males than in females. ${ }^{[37]}$

\section{CONCLUSION}

Maxillofacial injuries are mostly due to high velocity traffic. Management of these injuries have become easier with availability of miniplates and screws, because of which there is decrease in morbidity as little or no intermaxillary fixation is required. Therefore, we prefer to treat maxillofacial injuries with open reduction and internal fixation with miniplates and screws.

\section{REFERENCES}

[1] Phipps E, Shelton W. Forgoing medical treatment in severe facial trauma. J Trauma 1997;43:970-3.

[2] Hofman K, Primack A, Keusch G, et al. Addressing the growing burden of trauma and injury in low - and middle-income countries. Am J Public Health 2005;95(1):13-7.

[3] Chandran A, Hyder AA, Peek-Asa C. The global burden of unintentional injuries and an agenda for progress. Epidemiol Rev 2010;32(1):110-20.

[4] Shapiro AJ, Johnson RM, Miller SF, et al. Facial fractures in a level I trauma centre: the importance of protective devices and alcohol abuse. Injury 2001;32(5):353-6.

[5] Gassner R, Tuli T, Hächl 0, et al. Cranio-maxillofacial trauma: a 10 year review of 9, 543 cases with 21,067 injuries. J Craniomaxillofac Surg 2003;31(1):51-61.

[6] Lundin K, Ridell A, Sandberg N, et al. One thousand maxillo-facial and related fractures at the ENT-clinic in Gothenburg. A two-year prospective study. Acta Otolaryngol 1973;75(4):359-61.

[7] Alvi A, Doherty T, Lewen G. Facial fractures and concomitant injuries in trauma patients. Laryngoscope 2003;113(1):102-6.

[8] Hohlrieder M, Hinterhoelzl J, Ulmer H, et al. Traumatic intracranial hemorrhages in facial fracture patients: review of 2,195 patients. Intensive Care Med 2003;29(7):1095-100.

[9] Adeyemo WL, Ladeinde AL, Ogunlewe MO, et al. Trends and characteristics of oral and maxillofacial injuries in Nigeria: a review of the literature. Head \& Face Medicine 2005;1:7.

[10] WHO Statistics Annual 1992. Geneva: WHO, 1992.

[11] Layton S, Dickenson AJ, Norris S. Maxillofacial fractures: a study of recurrent victims. Injury 1994;25(8):523-5.

[12] Van Beek GJ, Merkx CA. Changes in the pattern of fractures of the maxillofacial skeleton. Int J Oral Maxillofac Surg 1999;28(6):424-8.

[13] Iida S, Kogo M, Sugiura T, et al. Retrospective analysis of 1502 patients with facial fractures. Int J Oral Maxillofac Surg 2001;30(4):286-90.

[14] Olasoji HO, Tahir A, Arotiba GT. Changing picture of facial fractures in northern Nigeria. $\mathrm{Br} \mathrm{J}$ Oral Maxillofac Surg 2002;40(2):140-3.

[15] Motamedi MH. An assessment of maxillofacial fractures: a 5 - year study of 237 patients. J Oral Maxillofac Surg 2003;61(1):61-4.

[16] Adebayo ET, Ajike OS, Adekeye EO. Analysis of the pattern of maxillofacial fractures in Kaduna, Nigeria. Br J Oral Maxillofac Surg 2003;41(6):396-400.

[17] Al Ahmed HE, Jaber MA, Abu Fanas SH, et al. The pattern of maxillofacial fractures in Sharjah, United Arab Emirates: a review of 230 cases. Oral Surg Oral Med Oral Pathol Oral Radiol Endod 2004;98(2):16670.

[18] Ansari MH. Maxillofacial fractures in Hamedan province, Iran: a retrospective study (1987-2001). J Craniomaxillofac Surg 2004;32(1):28-34. 
[19] Erol B, Tanrikulu R, Görgün B. Maxillofacial fractures. Analysis of demographic distribution and treatment in 2901 patients (25-year experience). J Craniomaxillofac Surg 2004;32(5):308-13.

[20] Laski R, Ziccardi VB, Broder HL, et al. Facial trauma: a recurrent disease? The potential role of disease prevention. J Oral Maxillofac Surg 2004;62(6):685-8.

[21] Cheema SA, Amin F. Incidence and causes of maxillofacial skeletal injuries at the Mayo Hospital in Lahore, Pakistan. $\mathrm{Br} \mathrm{J}$ Oral Maxillofac Surg 2006;44(3):232-4.

[22] Brasileiro BF, Passeri LA. Epidemiological analysis of maxillofacial fractures in Brazil: a 5-year prospective study. Oral Surg Oral Med Oral Pathol Oral Radiol Endod 2006;102(1):28-34.

[23] Kadkhodaie MH. Three-year review of facial fractures at a teaching hospital in northern Iran. Br J Oral Maxillofac Surg 2006;44(3):229-31.

[24] Al-Khateeb T, Abdullah FM. Craniomaxillofacial injuries in the United Arab Emirates: a retrospective study. J Oral Maxillofac Surg 2007;65(6):1094-101.

[25] Subhashraj K, Nandakumar N, Ravindran C. Review of maxillofacial injuries in Chennai, India: a study of 2748 cases. Br J Oral Maxillofac Surg 2007;45(8):637-9.

[26] Kelly DE, Harrigan WF. A Survey of facial fractures: Bellevue Hospital, 1948-1974. J Oral Surg 1975;33(2):146-9.

[27] Ugboko VI, Odusanya SA, Fagade 00. Maxillofacial fractures in a semi-urban Nigerian teaching hospital: a review of 442 cases. Int J Oral Maxillofac Surg 1998;27(4):286-9.

[28] Mala B, Ragacz D. Characteristics of maxillofacial injuries resulting from road traffic accidents. A 5 year review of the case records from department of Maxillofacial Surgery in Kotowise Poland. Med 2006;2:27-32.
[29] Ellis E 3rd, Moos KF, el-Attar A. Ten years of mandibular fractures: an analysis of 2,137 cases. Oral Surg Oral Med Oral Pathol 1985;59(2):120-9.

[30] Bataineh AB. Etiology and incidence of maxillofacial fractures in north of Jordan. Oral Surg Oral Med Oral Pathol Oral Rehabili Radio Endod 1998;86(1):31-5.

[31] Tay AG, Yeow VK, Tan BK, et al. A review of mandibular fractures in craniomaxillo facial trauma center. Ann Acad Med Singapore 1999;28(5):630-3.

[32] Kieser J, Stephenson S, Liston PN, et al. Serious facial fractures in New Zealand from 1979 to 1998. Int Journal Maxillofac Surg 2002;31(2):206-9.

[33] Ogundare BO, Bonnick A, Bayley N. Pattern of mandibular fractures in an urban trauma center. J Oral Maxillofac Surg 2003;61(6):713-8.

[34] Strom C, Nordenram A, Fischer K. Jaw fractures in the country of Koppanberg and Stochholmn 1979-1988: a retrospective comparative study of frequency and causes with special reference to assault. Swed Dent J 1991;15(6):285-9.

[35] Olkarinen K, Ignatius E, Kauppi H, et al. Mandibular fractures in Northern Finland in 1980s-a 10 year study. Br Journal Oral Maxillofac Surg 1993;31(1):237.

[36] Ozkaya O, Turgut G, Kayali MU, et al. A retrospective study on epidemiology and treatment of maxillofacial fractures. Ulus Trauma Acil Cerrahi Derg 2009;15(3):262-6.

[37] Agnihotri A, Galfat D, Agnihotri D. Incidence and pattern of maxillofacial trauma due to road traffic accidents: a prospective study. J Maxillofac Oral Surg 2014;13(2):184-8. 